\title{
E-Learning Capability Maturity During Covid 19 Pandemic - A Qualitative Approach
}

\section{Dr. H.M.R.P Herath ${ }^{1}$, Yasmeen BANO², Dr.S.Vasantha ${ }^{3^{*}}$}

\author{
${ }^{1}$ Professor, Department of Marketing Management, Faculty of Commerce and Management studies, University of Kelaniya, \\ Email: renukaherath@kln.ac.lk \\ ${ }^{2}$ Ph.D scholar, School of Management Studies, Vels Institute of Science, Technology \& Advanced Studies(VISTAS), \\ Chennai, India, Email: yasmeen11bano@gmail.com \\ ${ }^{3}$ Professor \& Research Supervisor, School of Management Studies, Vels Institute of Science, Technology \& Advanced \\ Studies(VISTAS), Chennai, India, Email: vasantha.sms@velsuniv.ac.in \\ ${ }^{*}$ Corresponding Author
}

\section{Received: 22.07.2021 $\quad$ Accepted: 11.08.2021 $\quad$ Published: 18.10.2021 $\quad$ DOI: $\underline{10.47750 / 0 A S / 22.184 .29}$}

\begin{abstract}
Background of the study: Learning system that had been previously carried out through face to face approach inside the class room switched to the online learning activities during the pandemic and the most common online methods of e - interaction are Webinars, via sharing online materials in Learning Management Systems and social media platforms such as Whatsapp. Tirziu\&Vrabie (2015) stated that online learning has become a standard component of various courses, which improve students' attitudes and learning capability and make them to become more competent therefore, it is important to explore online learning capabilities that students have developed among themselves as a result of extensive exposure to online learning during COVID-19 epidemic.

Objectives: This paper is based on above explained background therefore aimed to explore- learning capabilities that students have developed among themselves during the COVID19 pandemic.

Methodology - Semi-structured interviews were conducted from 30 selected respondents based on a developed interview guide. A thematic analysis was then carried out with the interview transcriptions and coding was done based on a tree coding strategy. Altogether eight themes were found as a mix of priori and in-vivo coding.

Findings: this study found various e- learning capabilities developed in students during the COVID-19 pandemic and revealed that online learning capability enhanced the students' motivation and confidence level. Students have become more aware and familiar about digital learning tools. The study also revealed that how the e-learning capability has been developed during the pandemic and found that there are various factors that helped students to enhance their e-learning capability.

Conclusion: This study is focused on identifying e-learning capability among the final year MBA students. Based on the result, it is concluded that students have developed various capabilities such as interpersonal capability, communication, confidence, attitude and cooperative learning. Further, the study also revealed the various approaches that help to identify the e-learning capability during the COVID-19 pandemic.

the study concluded that e- learning capabilities have been significantly developed in during the COVID-19 pandemic and they have become more familiar with the digital learning tools. It helps to create the user friendly environment that motivates and increases their confidence.
\end{abstract}

Key words - COVID - 19 pandemic, e- learning capabilities, online learning, learners' perception, skills.

\section{Introduction}

The COVID 19 pandemic has prevented more than 1 billion students around the world attending schools, colleges and universities. Lockdown restrictions have given rise to a boom in online learning and home-schooling. Saye (2001) defines elearning as electronic resources that are generated through the electronic medium and it is made available to the large number of viewers via internet/ electronic transferring machine. Relan and Gillani (1997), Internet based learning environment helps students to organize and learn the content. French, Hale, Johnson, and Farr (1999), in online environments, students have more control on time and pace, learning outcome and study objectives.

The maximum immediate effect of the students has naturally been that the temporary cessation of face to face learning activity at higher education institutions has left them, specially undergraduates and those who are about to finish higher secondary and aspire to go into higher education, in a completely new circumstances. Therefore, online learning helps them to enhance their learning capability through various webinars, face to face online learning, e- study material and so on. Prahalad \& Hamel (1990), capability refers abilities, set of skills or competencies and expertise of a person within the organization. Jabli and Qahmash (2013), Online learning has become one of the critical strategic elements which utilized to improve students skill, attitude, performance and educational outcomes. E-learning increases the students' ability of developing learning strategies, improves self-directed learning, 
makes less dependent on teacher and others, increases communication and interaction skills and develop the creativity skill (Collison et al., 2000).

\section{Objectives}

What e-learning capabilities of students have been developed during COVID-19 pandemic?

How those identified capabilities have been developed during COVID-19 pandemic?

\section{Literature Review}

Currently, online learning considers as an important element in the educational system when all the institutions are closed due to COVID 19 pandemic. Nagarajan and Jiji (2010), E- learning become as a critical aspects in the educational sectors that implemented innovative change in the learning environment. Bridges (1993), investigates various learning capabilities such as transferable skills, core and generic skills and he relates these skills to more fundamental and commonly applicable in learning. U.S. has developed a new learning model in the previous decade. The new learning model is called 21st century skills which are focused on the essential skills that students should have for their future career and to be more competitive (Jenkins, 2009; Wagner, 2008). Phillips, et al. (2012), Effective e learning can enhance the students capability, attitude and educational opportunities and also helps them to developing their skills which they need in 21 century. Jabli and Qahmash (2013), e-learning has become one of the critical strategic elements which utilized to improve students' learning capability, attitude, performance and educational outcomes. Marshall (2013), aimed at helping educational institutions by the e-learning Maturity Model which provide understanding of current organizational e- learning capability and also provide the tools aimed at systematically improving that capability. Iskander and Daflous (2013), though, e-learning is a strategic element that is adopted for improving educational outcomes, students' skills and organizational performance. Morrison (2016), digital skills are essential in the field of education, because it replaces the traditional methods of teaching and learning and it helps to manage the effective and efficient teaching learning practices. Metilda and PC (2017), digital technology supports the skill attainments, develop learning capability and improves the efficiency of educational system.

Soft skills are basic and fundamental skill of students' lives that comprise problem solving skill, communication skill, creativity skill, teamwork, self-management, negotiating capability, determination and passion. In a simple form, it can be categorizez as interpersonal skills, personal qualities and other addition knowledge and capability (Schulz, 2008).

Chung(2016) states that communication skill is very critical skill in 21 st century to achieve success. Therefore, students need to put more focus on improving effective communication.He also suggested communication skill improves by constructing the shared knowledge and continuously interacting with peers. It can be built by communicating activities such as problem solving, discussion and oral presentation (Oradee, 2012).

Presentation skill is also important for achieving success in all the aspects of students' lives. Presentation capability should include clear statements, clear explained ideas, support those ideas with the related evidence and clear conclusion (Hamm \& Dunbar, 2006). Therefore, students need to be trained by providing self-observation of their presentation and giving feedback. It is crucial to prepare students in this competitive environment (Shauki \& Benzie, (2014). Presentation skill can be enhanced by accessible technology e.g. video hosting services to deveop their professional speaking capability (Kenkel, 2011).

León et.al., (2011), Cooperative learning is the innovative methodology that helps in solving the most critical problems in educational field like lack of motivation, failure, bullying, student-teacher interaction and of course treatment of multiculturalism. Boyer (1990), emphasized cooperation is necessary in the academic programs, especially in the classroom procedures, therefore students should be asked to participate in the collaborative projects to work occasionally through the seminar.

\section{Methodology}

This is a qualitative study so 30 students from postgraduate courses those are from three different universities were interviewed. The selected students are those whom engaged in online lectures, presentations and discussions at the time study was conducted. The interviews were also carried via Zoom and over the telephone as the study was also carried out during lock down situation. The interview guide was prepared with the support of reviewed literature. Interviews were reordered and then transcribed for the purpose of data analysis. The interview transcriptions were read many times by the researchers to be familiarized with the contents of the transcription and also all the interviews were carried out by the researchers themselves which improved the familiarity with the research data as in qualitative research the interpretation of data becomes critical when researchers do not know their own data (Yin, 1994). A the thematic analysis was carried out and data coding was a Tree Coding strategy as themes were identified under the two main categories of identified e-learning capabilities and factors that have helped to develop identified e-learning capabilities. Under the first parent code, five child codes were identified and three child codes were found under the second parent code. These themes were identified as a mix of priori and in-vivo coding strategies.

\section{Findings}

The purpose of the study is to identify and explore the elearning capabilities in the midst of COVID 19 pandemic and what are the contributed factors to develop them so the findings are organized three main themes as follows;

\subsection{Identified E- Learning Capabilities That Have Been Developed During Covid-19 Pandemic}

As all the universities and colleges closed their campus to face the spread of COVID 19 pandemic and moved their classes in online format. In the response of demand, many online learning platforms are offering free access services to improve the students' learning ability.

\subsection{Collaborative learning increases the confidence and students attitude towards social activity}

Collaboration: Students views, "User friendly environment motivates me to learn and increases my confidence."Students said, "User friendly environment enhance the collaborative learning."Liaw \& Huang (2013).A user friendly interactive learning environment can positively enhance a students'attitude toward using e-learning tools.Stahl et.al.(2006), collaborative 
learning helps the learners to look for information through the internet, discuss, summarize it together and present it which construct a discourse that provides the possibility to motivate the students and it also helps to create the social presence. Roschelle and Teasley (1995), Collaborative learning is a social activity which is based on the construction of shared knowledge in collaborative problem solving. Dick et.al. (2009), Collaborative research projects reduce the authoritarian knowledge and provide the confidence to the participants.

\subsection{Digital learning tools enhance communication and interaction among the students and teachers}

Digital learning: Students stated "by using online classes we become more familiar with the online and digital learning tools." One more student stated, "We have got the opportunity and developed our communication skill professionally by the simulated court". Also said, "we have learned to convey our ideas to one and another". Digital learning tools during COVID19 have been deeply impacted on all domains in students' life. It has been triggered dramatic changes in way of communication with one and another and interaction of the students with the content. Glenn (2008), Digital learning technology brought sophisticated learning management system, distance learning tools and social networking tools. These technologies are shaping the learners way of thinking and behaving. Dede (2009), in order to success in their professional life, a learner needs to develop the emerging skills such as innovation skills, media and technology skills and career skills. Doyle (2016), Skills in this digital era is also called hard skills including digital literacy skills and soft skills which refer to adaptability, flexibility and information processing.

\subsection{Instant messaging encourages students to discuss freely}

Instant messaging: Regarding discussion students said,"whatsapp group is more helpful for discussing freely."They also affirmedit by saying, "It is very helpful for discussing the assignments because whole class is involved."Bere (2012), WhatsApp messenger has several collaborative features such as multimedia, group chats, unlimited messaging which allows users to exchange videos, images, voice notes and it supports to interact which other. Amry (2014),compares the effectiveness of WhatsApp with face to face learning in the classroom Plana et al. (2013), demonstrated the positive impact of instant messaging system on their regularity and confidence in reading skill among the students.

\subsection{Effective interpersonal contact motivates student to give clear statement}

Interpersonal contact: As explained, e learning capability is radical for the students in higher education in 21 st century. In general, large numbers of e learners are online users. They can develop their e learning capability anytime, anywhere. Thus, students should learn some learning delivery capability to achieve effective e- learning environment. For instance, elearners should have capability of developing e-learning skills including use e- learning materials, e- learning strategies, interaction and communication skills, creativity skill and self directed learning (Yang \& Liu, 2005; Collison et al., 2000; Francescato et al., 2006).

Students confirm, "Effective interpersonal contact builds strong relation among the peers and enhance the trust level"."Good interpersonal skill enhances understanding between teacher and students". Sometimes lack of direct interpersonal contact is a challenge for the teaching instructors. Students' feedback is more important for online learning, it helps to give the clarity of their communication but indirect and delayed feedback makes it challenge for the instructors to understand the students learning capability. Therefore, lack of interpersonal contact makes difficult to assess the students understanding and response (Bower, 2001). Thus, it is necessary to provide new e-learning capability and skills to deliver online instructions. They need to move their educational experience to learner-centered education. To provide learning motivation to the e-learner they must design new teaching strategies, invite learners for active participation in the interaction process.

\subsection{Cooperative learning improves teaching learning method}

Cooperative learning: Cooperative learning is beneficial when it is designed effectively. One of student affirmed during interview, "Cooperative learning develops critical thinking skill". Other students supported this statement. Cooperative learning enhances students' attitude and achievements about learning (Johnson et al., 2007). Though it does require essential modification to manage the classroom and improve their teaching. Learning method, learning motivation, course requirement and socialization model has changed in e-learning environment (Webster \& Hackley, 1997). Thus, research indicates that cooperative learning develops students' social skills and improves their achievements. Cooperative learning is effective but there is some potential disadvantages of it, so instructors should be more aware and attentive during the elearning process (Yang \& Liu, 2005).

\section{Approaches And Activities That Help To Develop E-Learning Capabilities Among The Students}

\subsection{Time Management Strategy}

Students those have responded to interview questions on developing e- learning capabilitywere asked about activities and approaches that they found most helpful. Most of the students expressed that time management strategy was more helpful during the online learning process. One student commented, "Establishing the time schedule for the study was one of the factor that worked for me," another student stated, "setting the specific time for the study and discussing assignments proved helpful." Time management is essential in education field to use the time correctly that develops critical skills and autonomy of the students (ECTS, 2015).

\subsection{Online discussion}

Is another important aspect on that the students have commented, "interaction with the other students built good relationship and effective communication." One more student stated, "Online discussions encourage students to ask 'why' and 'how' questions."

Making good connection with the fellow students also encourages in the learning process. Students said, "Interaction with fellow students motivates you to develop your learning skills."

\subsection{User friendliness of the digital technology}

In the education field, digital technologies offer many opportunities to increase the capability among students. It transforms the previous learning models and relationship 
between knowledge and learning process (Duderstadt, 1994).

Digital learning supports by the digital technologies. It makes substantial contribution in the improvement of educational outcome and it offers opportunities to develop digital skills. Students said, "Effective use of digital technology makes the learner more creative." Another affirmed, "Best use of digital technology enhances digital skill which is essential in today's digitized environment."Jisc (2014), Digital literacy refers the capability that makes individuals for learning and working in digitized society. He also stresses that digital literacy makes individual more digitized rather than gaining the particular knowledge.

\section{Discussion}

The paper aims to examine the various Online Learning capabilities in the midst of a COVID-19 pandemic and to discuss various factors which helps to develop e- learning capability in the midst of COVID - 19 pandemic. The Capabilities refers the interaction between human and material resources (Penrose, 1959), so the capabilities can be defined as abilities, skills and expertise of the person or group within the organization. (Rothwell \& Lindholm, 1999). The study reveals that learners' perception on online learning is effective in the midst of COVID 19 pandemic. It is also proved that online learning is very helpful for the students in the middle of the crisis. Popovici and Mironov (2014), investigated that students are become more aware of digital leaning technologies and the impact of learning process. Further the study explored the effectiveness of online learning during the pandemic. Studies indicated that online learning helps students' motivation, their engagement with the work that is most important in the process of learning. Effective learning improves the students' performance in their specialized field and it also promotes the skills that are required in the current job market. Kiboss \& Ogunniyi (2005), found that dictation web based learning program makes better progress in dictation among the students as compared to those students who uses traditional method of learning.

The responses of the students also highlighted how the elearning capability can be developed. Most important method to develop students' ability is time management strategy that helps in fulfill the study requirement of self- learner. Another important aspect that students have highlighted is online discussion that improves e-learning capability and motivates students to learn more. Making good connections with the fellow students also keep them motivated.

Furthermore, the study questioned about impact of digital technology in the development of e-learning capability, and found digital technology plays an important role to improve the capability among the students.

\section{Conclusion}

The study provides better understanding e-learning capability or how e-learning impacted the capability of students. This research has focused on identifying e-learning capability among the final year students. Based on the result of the study, it can be concluded that students' perception on online learning is good in the midst of COVID 19 pandemic. It is also proved that online learning is very helpful for the students and it increases the capability of the students. Learners' e- learning capability has increased and they become more familiar with the digital skills that help them motivated and increased their confidence. Moreover, the study presents the effectiveness of e- learning capability during the pandemic. Dorrian \& Wache (2009), effective e-learning provides many benefits to the learner e.g. improves the quality of learning, increases the flexibility and it also develop the basic skills among the students.

\section{References}

[1] Amry, A. B. (2014). The impact of WhatsApp mobile socia learning on the achievement and attitudes of female students compared with face to face learning in the classroom.

[2] Bhuasiri, W., Xaymoungkhoun, O., Zo, H., Rho, J. J., \& Ciganek, A. P. (2012). Critical success factors for e-learning in developing countries: A comparative analysis between ICT experts and faculty. Computers \& Education, 58(2), 843-855. doi: 10.1016/j.compedu.2011.10.010

[3] Bridges, D. (1993). Transferable skills: A philosophical perspective. Studies in Higher Education, 18(1), 43-51. doi: 10.1080/03075079312331382448

[4] Boyer, E. (1990). Scholarship reconsidered. Lawrenceville, NJ: Princeton University Press.

[5] Bower, B. L. (2001). Distance education: Facing the faculty challenge. Online Journal of Distance Learning Administration, 4(2).

[6] Bere, A. (2012, September). A comparative study of student experiences of ubiquitous learning via mobile devices and learner management systems at a South African university. In 2012 Conference.

[7] Collison, G., Elbaum, B., Haavind, S., \& Tinker, R. (2000). Facilitating online learning: Effective strategies for moderators. Atwood Publishing, 2710 Atwood Ave., Madison, WI 53704

[8] Creswell, J. W. (2012). Educational research: planning, conducting, and evaluating quantitative and qualitative research. Boston: Pearson Education, Inc

[9] Crossroads : Higher Education in Latin America and the Caribbean. Washington, DC: World Bank.

[10] Chung, Y., Yoo, J., Kim, S.-W., Lee, H., \& Zeidler, D. L. (2014). ENHANCING STUDENTS' COMMUNICATION SKILLS IN THE SCIENCE CLASSROOM THROUGH SOCIOSCIENTIFIC ISSUES. International Journal of Science and Mathematics Education, 14(1), 1-27. doi: 10.1007/s10763-014-9557-6

[11] Chaney, E. G. (2001). Web-based Instruction in a Rural High School: A Collaborative Inquiry into Its Effectiveness and Desirability. NASSP Bulletin, 85(628), 20-35. doi: 10.1177/019263650108562803

[12] Dick, B., Stringer, E., \& Huxham, C. (2009). Final reflections, unanswered questions. Action Research, 7(1), 117-120. doi: $10.1177 / 1476750308099601$

[13] Dede, C. (2010). Comparing frameworks for 21st century skills. 21st century skills: Rethinking how students learn, 20(2010), 51-76.

[14] Doyle, A. (2016). Hard skills vs. soft skills. The balance. Retrieved from https://www.thebalance.com/hard-skills-vs-softskills-2063780

[15] Dorrian, J., \& Wache, D. (2009). Introduction of an online approach to flexible learning for on-campus and distance education students: Lessons learned and ways forward. Nurse Education Today, 29(2), 157-167. doi: 10.1016/j.nedt.2008.08.010

[16] Duderstadt, J.J. (1994), "The university of the 21st century", presented at the Meeting of the American Society for Information Science, Portland, OR.

[17] ECTS (2015), "Users' guide 2015", European Credit Transfer and Accumulation System, European Commission, available at: http://ec.europa.eu/dgs/education_culture/repository/education/ library/publications/2015/ects-users-guide_en.pdf

[18] Fraenkel, J. R. \& Wallen, N. E. (2003). How to design and evaluate research in education (5th ed.). New York: McGrawHill

[19] Francescato, D., Porcelli, R., Mebane, M., Cuddetta, M., 
Klobas, J., \& Renzi, P. (2006). Evaluation of the efficacy of collaborative learning in face-to-face and computer-supported university contexts. Computers in Human Behavior, 22(2), 163176. doi: 10.1016/j.chb.2005.03.001

[20] French, D., Hale, C., Johnson, C., \& Farr, G. (Eds.). (1999). Internet based learning: An introduction and framework for higher education and business. Sterling, VA: Stylus.

[21] Glenn, M. (2008). The future of higher education: How technology will shape learning (pp. 1-27). The New Media Consortium.

[22] Henderson, R., \& Cockburn, I. (1994). Measuring Competence? Exploring Firm Effects in Pharmaceutical Research. Strategic Management Journal, 15(S1), 63-84. doi: 10.1002/smj.4250150906

[23] Hamm, P. H., \& Dunbar, N. R. (2006). Teaching and persuasive communication: class presentation skills. Brown University, 1012.

[24] George Maher Iskander, \& George Daflous. (2012). Exploration of Qualitative Evidence: Towards Construction of Maturity Model for E-learning. International Journal on Data Mining and Intelligent Information Technology Applications, 2(2), 56-65. doi: 10.4156/ijmia.vol2.issue2.6

[25] Jabli, N. and Qahmash, A. (2013), "The Benefits and Barriers of E-learning in Higher Education in Saudi Arabia", Journal of Emerging Trends in Computing and Information Sciences, 4(1), 877-880.

[26] Jenkins, H. (2009). Confronting the Challenges of Participatory Culture. doi: $10.7551 /$ mitpress/8435.001.0001

[27] Johnson, D. W., Johnson, R. T., \& Smith, K. (2007). The State of Cooperative Learning in Postsecondary and Professional Settings. Educational Psychology Review, 19(1), 15-29. doi: $10.1007 / \mathrm{s} 10648-006-9038-8$

[28] JISC (2014). Developing Digital Literacieshttps://www.jisc.ac.uk/guides/developing-digitalliteracies.

[29] Kiboss, J. K., \& Ogunniyi, M. B. (2005). Outcomes of first year secondary students in a computer-augmented physics program on measurement. Learning, Media and Technology, 30(3), 313326. doi: $10.1080 / 17439880500251442$

[30] Kenkel, C. S. (2011). Teaching presentation skills in online business communication courses. MERLOT Journal of Online Learning and Teaching, 7(3), 412-418.

[31] Leon, B., Felipe, E., Iglesias, D., \& Latas, C. (2011) Cooperative learning in the initial training of secondary school teachers. REVISTA DE EDUCACION, (354), 715-729.

[32] Liaw, S.-S., \& Huang, H.-M. (2013). Perceived satisfaction, perceived usefulness and interactive learning environments as predictors to self-regulation in e-learning environments. Computers \& Education, 60(1), 14-24. doi: 10.1016/j.compedu.2012.07.015

[33] Marshall, S. (2013). Using the e-learning maturity model to identify good practice in e-learning. In ASCILITE-Australian Society for Computers in Learning in Tertiary Education Annual Conference (pp. 546-556). Australasian Society for Computers in Learning in Tertiary Education.

[34] Morrison, D. (2016). Higher ed's digital skills gap: Faculty and students. Online Learning Insights.

[35] Metilda, R. M., \& PC, N. (2017). Impact of digital technology on learning to enhance the employability skills of business management graduates. The Online Journal of Distance Education and e-Learning, 5(2), 35.

[36] Nagarajan, P. and Jiji, W. (2010), "Online Educational System (e- learning)", International Journal of u- and eService, Science and Technology, 3(4), 37-48.

[37] Oradee, T. (2013). Developing Speaking Skills Using Three Communicative Activities (Discussion, Problem-Solving, andRole-Playing). International Journal of Social Science and
Humanity, 533-535. doi: 10.7763/ijssh.2012.v2.164

[38] Popovici, A., \& Mironov, C. (2015). Students' Perception on Using eLearning Technologies. Procedia - Social and Behavioral Sciences, 180, 1514-1519. doi: 10.1016/j.sbspro.2015.02.300

[39] Petrides, L. A. (2002). Web-based technologies for distributed (or distance) learning: Creating learning-centered educational experiences in the higher education classroom. International journal of instructional media, 29(1), 69.

[40] Phillips, V. (2002), "Why does corporate e-learning fail? Virtual University Gazette, June

[41] Penrose, E. (1959). The Theory of the Growth of the Firm '(Oxford: Basil Blackwell).

[42] Prahalad, C. K., \& Hamel, G. (1990). The Core Competence of the Corporation. Harvard Business Review, 68(3), 79-92.

[43] Plana, M. G. C., Escofet, M. I. G., Figueras, I. T., Gimeno, A., Appel, C., \& Hopkins, J. (2013). Improving learners' reading skills through instant short messages: A sample study using WhatsApp.

[44] Rothwell, W. J., \& Lindholm, J. E. (1999). Competency identification, modelling and assessment in the USA International Journal of Training and Development, 3(2), 90105. doi: 10.1111/1468-2419.00069

[45] Relan, A., \& Gillani, B. B. (1997). Web-based instruction and the traditional, classroom: Similarities and differences. Web-Based Instruction. Englewood Cliffs, New Jersey: Educational Technology Publications, pp. 41-46.

[46] Roschelle, J., \& Teasley, S. D. (1995). The Construction of Shared Knowledge in Collaborative Problem Solving. Computer Supported Collaborative Learning, 69-97. doi: 10.1007/978-3642-85098-1_5

[47] Stahl, G., Koschmann, T., \& Suthers, D. (2006). Computersupported collaborative learning: An historical perspective [Electronic Version]. Retrieved 2007-06-07 from http://lilt. ics. hawaii. edu/lit/papers/2006/CSCL_American_English. pdf.

[48] Schulz, B. (2008). The importance of soft skills: Education beyond academic knowledge.

[49] Saye, J. D. (2001). The organization of electronic resources in the library and information science curriculum. OCLC Systems \& Services: International Digital Library Perspectives, 17(2), 7178. doi: $10.1108 / 10650750110383604$

[50] Shauki, E. R., \& Benzie, H. (2014). Enhancing Students Oral Presentation Skills: Observation Based on Undergraduate Accounting Students. Asia Pacific Journal of Accounting and Finance, 3, 43-58.

[51] Tîrziu, A.-M., \& Vrabie, C. (2015). Education 2.0: E-Learning Methods. Procedia - Social and Behavioral Sciences, 186, 376380. doi: 10.1016/j.sbspro.2015.04.213

[52] Webster, J., \& Hackley, P. (1997). Teaching Effectiveness in Technology-Mediated Distance Learning. Academy of Management Journal, 40(6), 1282-1309. doi: 10.5465/257034

[53] Wagner, T. (2008). Transforming education even our "best" schools are failing to prepare students.

[54] Yang, Y., \& Cornelius, L. F. (2004). Students' perceptions towards the quality of online education: A qualitative approach. Association for Educational Communications and Technology.

[55] Yang, S. C., \& Liu, S. F. (2005). The study of interactions and attitudes of third-grade students' learning information technology via a cooperative approach. Computers in Human Behavior, 21, 45-72.

[56] Yin, R. K., (1994). Case Study Research Design and Methods: Applied Social Research and Methods Series. Second edn. Thousand Oaks, CA: Sage Publications Inc.

[57] Retrieved from https://www.bestcolleges.com/blog/coronavirusimpacts-on-students/ 